University of Nebraska - Lincoln

DigitalCommons@University of Nebraska - Lincoln

Faculty Publications from the Harold W. Manter Laboratory of Parasitology

2002

\title{
A Preliminary Analysis of Proteolytic Activity of Excretory- Secretory Products from Cyathostominea
}

Jane L. Kinsella

University College Dublin

J. Ralph Lichtenfels

Animal Parasitic Disease Lab, ARS, United States Department of Agriculture, 2jrcgl@gmail.com

Michael F. Ryan

University College Dublin, mfryan@ucd.ie

Follow this and additional works at: https://digitalcommons.unl.edu/parasitologyfacpubs

Part of the Parasitology Commons

Kinsella, Jane L.; Lichtenfels, J. Ralph; and Ryan, Michael F., "A Preliminary Analysis of Proteolytic Activity of Excretory-Secretory Products from Cyathostominea" (2002). Faculty Publications from the Harold W. Manter Laboratory of Parasitology. 629.

https://digitalcommons.unl.edu/parasitologyfacpubs/629

This Article is brought to you for free and open access by the Parasitology, Harold W. Manter Laboratory of at DigitalCommons@University of Nebraska - Lincoln. It has been accepted for inclusion in Faculty Publications from the Harold W. Manter Laboratory of Parasitology by an authorized administrator of DigitalCommons@University of Nebraska - Lincoln. 


\title{
A preliminary analysis of proteolytic activity of excretory-secretory products from Cyathostominea
}

\author{
Jane L. Kinsella ${ }^{\text {a }}$, J. Ralph Lichtenfels ${ }^{\mathrm{b}}$, Michael F. Ryan ${ }^{\mathrm{a}, *}$ \\ a Department of Zoology, University College Dublin, Belfield, Dublin 4, Ireland \\ ${ }^{\mathrm{b}}$ Animal Parasitology Institute, Beltsuille Agricultural Research Centre, ARF, USDA, \\ Beltsuille, Maryland 20705, USA
}

Received 24 September 2001; received in revised form 28 February 2002; accepted 4 April 2002

\begin{abstract}
The excretory-secretory product (ESP) derived from Cyathostominea in vitro was assessed, in terms of subunit composition, and proteolytic activity using as substrates azocasein and two synthetic fluorogenic peptides. Sodium dodecyl sulphate-polyacrylamide gel electrophoresis (SDS-PAGE) resolved 13 subunits, and the presence of the protein cysteine proteinase activator dithiothreitol (DTT) revealed 21 subunits. DTT also enhanced azocaseinolysis, and hydrolysis of carbobenzoxy-phenylalanyl-arginine-7-amido-4-methylcoumarin (Z-Phe-Arg-NHMec) and carbobenzoxy-arginyl-arginine-7-amido-4-methylcoumarin (Z-Arg-Arg-NHMec). At the optimum $\mathrm{pH}$ of 5.5, hydrolysis of Z-Phe-Arg-NHMec was three-fold greater than that of Z-Arg-Arg-NHMec suggesting that the proteolytic specificities of the ESP are more like those of papain or cathepsin L, rather than cathepsin B. In SDS-PAGE gelatin gels, DTT was a requirement for proteolysis by the ESP. Optimum resolution was at $\mathrm{pH}=5.5$, resolving six bands ranging from $114-20 \mathrm{kDa}$. Cysteine proteinase inhibitors abolished all gelatinolytic activity at the $\mathrm{pH}$ values tested. Such data indicate the presence of cysteine-class proteinases in the ESP of Cyathostominea. ( 2002 Elsevier Science B.V. All rights reserved.
\end{abstract}

Keywords: Cyathostominea; Excretory-secretory product (ESP); Cysteine proteinases

\section{Introduction}

Nematodes of the subfamily Cyathostominea are now regarded as the principal parasitic pathogens of the horse, Equus caballus (Langrova, 1998). The marked decline in prevalence of large strongyle infections has not dramatically reduced the occurrence of

\footnotetext{
* Corresponding author. Tel.: +353-1-716-2345; fax: +353-1-716-1152.

E-mail address: mfryan@ucd.ie (M.F. Ryan).
} 
strongyle-associated disease, and clinical attention is now focusing on the pathogenicity of cyathostomins. More than 50 species of Cyathostominea have been documented (Lichtenfels et al., 1998) and infected horses often harbour burdens of tens of thousands of cyathostomins, mostly comprising 5-10 common species (Gawor, 1995).

Adult worm burdens are subclinically associated with general debilitation, weight loss, poor appetite, and disordered intestinal motility (Matthews and Morris, 1995). Cyathostomins have also been associated with a non-specific mild equine colic (Uhlinger, 1990), and specific forms of colic, including non-strangulation infarction (Mair and Pearson, 1995), caecocaecal intussusception (Mair et al., 2000), and caecal tympany (Murphy et al., 1997). These parasites are further associated with a distinctive and acute clinical syndrome known as larval cyathostominosis. The syndrome has a case fatality rate of $50 \%$ (Love and McKeand, 1997), and is a potentially fatal enteritis which is directly associated with the synchronous mass emergence of developing larvae from the caecal and colonic mucosa (Abbott, 1998).

There is a paucity of information surrounding the detailed biology and pathogenic mechanisms of the cyathostomins. In particular, there seems to be no quantification of proteolytic activities in Cyathostominea and their role in pathogenicity.

Proteinases may play a crucial role in the pathogenicity of cyathostomin infections as shown for other parasites such as Anisakis simplex, Schistosoma mansoni and Fasciola hepatica (Morris and Sakanari, 1994; Smith et al., 1994; Halton, 1997, respectively). Their biological functions may include digestion of host protein for acquisition of nutrients, facilitation of migration through tissues, and inactivation of host immune effector molecules (Gotz and Klinkert, 1993; Song and Kim, 1994; Smith et al., 1993).

Furthermore, proteinases also serve as potential targets for serodiagnosis and vaccine development, as has been shown for F. hepatica, S. mansoni, Paragonimus westermani and Haemonchus contortus (Cornelissen et al., 2001; Grogan et al., 1997; Ikeda et al., 1996; Jasmer et al., 2001, respectively). This study presents a preliminary analysis of proteolytic activity in the excretory-secretory product (ESP) of Cyathostominea. The identities, prevalence, and intestinal distribution of Cyathostominea in Ireland, will be the subject of a future report (Kinsella, Lichtenfels and Ryan, in preparation).

\section{Materials and methods}

\subsection{Preparation of excretory-secretory products (ESP) from Cyathostominea}

On 14 separate occasions between November 1997 and August 1998, Cyathostominea were removed from the intestinal contents, caecal walls, and ventral and dorsal colon of 63 horses, freshly slaughtered at the Irish Horse Abattoir Trading Co. Ltd., (Straffan, Co. Kildare Ireland). The parasites were removed with the aid of fine forceps and horse hair paintbrushes, placed in RPMI-1640 medium (Dutch Modification), $\mathrm{pH}=7.3$, containing $200 \mathrm{IU} \mathrm{ml}^{-1}$ streptomycin, $200 \mu \mathrm{g} \mathrm{ml}^{-1}$ penicillin, $20 \mu \mathrm{g} \mathrm{ml}^{-1}$ gentamicin, $4 \mu \mathrm{g} \mathrm{ml}^{-1}$ amphotericin $\mathrm{B}$, and $0.5 \%(\mathrm{w} / \mathrm{v})$ glucose at $37^{\circ} \mathrm{C}$ and immediately transported to the laboratory. The worms were washed extensively in RPMI- 1640 at $37^{\circ} \mathrm{C}, \mathrm{pH}=7.3$, prior to the collection of ESP. 
Batches of worms incubated at $37^{\circ} \mathrm{C}$ in the above medium ( $15-50$ per $5 \mathrm{ml}$ ) were checked every $8 \mathrm{~h}$ to remove non-motile worms. The medium was replaced after $24 \mathrm{~h}$ and incubations usually continued for $48 \mathrm{~h}$. The collected medium was sterile-filtered through a $0.2 \mu \mathrm{m}$ millipore filter, and concentrated 20-fold over a YM10 flat ultrafiltration membrane, cut-off at $10 \mathrm{kDa}$, in a Model 8010 ultrafiltration cell at $4{ }^{\circ} \mathrm{C}$. ESP was frozen in liquid nitrogen and stored at $-70^{\circ} \mathrm{C}$. The ESP from the 14 occasions was pooled for this study and was concentrated a further 15 -fold using microconcentrators, cut-off at $3 \mathrm{kDa}$ (Amicon). ESP was again frozen in liquid nitrogen and stored at $-70{ }^{\circ} \mathrm{C}$. The nematodes were cleared in phenol-alcohol (80\% melted phenol crystals and $20 \%$ absolute ethanol) and stored in $70 \%$ ethanol. Identifications were made with the aid of a light microscope using the keys of Lichtenfels (1975) and Lichtenfels et al. (1997); names of the cyathostomin species follow the recommendations of Lichtenfels et al. (1998). The Bradford method (Bradford, 1976) was used to ascertain protein concentrations.

\subsection{Sodium dodecyl sulphate-polyacrylamide gel electrophoresis}

SDS-PAGE was carried out in mini slab gels (ATTO corporation). Samples incorporating $10 \mu \mathrm{l} \mathrm{ESP}$ and $5 \mu \mathrm{l}$ sample buffer $\left(187.5 \mathrm{mM}\right.$ Tris- $\mathrm{HCl}\left(\mathrm{pH}=6.8\right.$ at $\left.25^{\circ} \mathrm{C}\right), 6 \%(\mathrm{w} / \mathrm{v})$ SDS, $30 \%$ glycerol and $0.03 \%(\mathrm{w} / \mathrm{v})$ phenol red), were boiled for $1 \mathrm{~min}$ in the presence or absence of $5 \mathrm{mM}$ dithiothreitol (DTT; Sigma). Samples were applied to a 3\% stacking gel and resolved through a $12.5 \%$ resolving gel (Laemmli, 1970), over $3 \mathrm{~h}$ at room temperature. After electrophoresis, gels were fixed and stained using the Biorad ${ }^{\circledR}$ Silver Staining procedure, and were analysed using GeneTools (Syngene).

Molecular weight markers (Sigma) were as follows: MBP-ß-galactosidase (175 kDa), MBP-paramyosin (83 kDa), glutamic dehydrogenase (62 kDa), aldolase (47.5 kDa), trisphosphate isomerase $(32.5 \mathrm{kDa})$, ß-lactoglobulin A $(25 \mathrm{kDa})$, lysozyme, (16.5 kDa) and aprotinin $(6.5 \mathrm{kDa})$.

\subsection{Azocasein as a substrate}

Activities of proteinases in solution were estimated using azocasein as a substrate. Assays at $37^{\circ} \mathrm{C}$ incorporated $10 \mu \mathrm{l} \mathrm{ESP}(1.76 \mu \mathrm{g}$ protein $)$, and $500 \mu \mathrm{l}$ of a designated buffer, $0.1 \mathrm{M}$ sodium citrate $(\mathrm{pH}=3-5), 0.1 \mathrm{M}$ sodium phosphate $(\mathrm{pH}=6$ and 6.5$)$ and $0.1 \mathrm{M}$ Tris-HCl ( $\mathrm{pH}=7-9$ ) containing $0.25 \%(\mathrm{w} / \mathrm{v})$ azocasein (Sigma). DTT when added, was at a final concentration of $5 \mathrm{mM}$. The reaction was stopped by adding an equal volume of $10 \%$ (w/v) trichloroacetic acid (TCA). Centrifugation followed at $13,000 \mathrm{rpm}$ for $10 \mathrm{~min}$ in a Heraeus Sepatech microcentrifuge, to remove undigested material. Supernatant absorbances at $366 \mathrm{~nm}$ were determined in a Beckman DU ${ }^{\circledR} 650$ spectrophotometer, and activity was expressed as $\mu \mathrm{mol}$ azopeptides released $\mathrm{min}^{-1} \mathrm{mg}^{-1}$ protein. $E_{366}^{1 \%}$ of azopeptides was taken as 40 .

\subsection{Synthetic fluorogenic substrates}

Proteinase activity was measured fluorometrically using the synthetic peptides, carbobenzoxy-phenylalanyl-arginine-7-amido-4-methylcoumarin (Z-Phe-Arg-NHMec) and 
carbobenzoxy-arginyl-arginine-7-amido-4-methylcoumarin (Z-Arg-Arg-NHMec, Sigma). The reaction mixture contained $102.5 \mu \mathrm{l}$ of a designated buffer and $2.5 \mu \mathrm{l}(0.44 \mu \mathrm{g}) \mathrm{ESP}$ pre-incubated for $10 \mathrm{~min}$ at $37^{\circ} \mathrm{C}$. The reaction was started by introducing one of the peptide substrates (Z-Phe-Arg-NHMec) or (Z-Arg-Arg-NHMec), bringing the final substrate concentration to $35 \mu \mathrm{M}$. When present, DTT was at a final concentration of $5 \mathrm{mM}$. Reactions were stopped by the addition of iodoacetic acid (IA) to a final concentration of $10 \mathrm{mM}$ following incubation at $37^{\circ} \mathrm{C}$, for $12 \mathrm{~min}$ in the presence of DTT and for $20 \mathrm{~min}$ in its absence. Fluorescence was measured in a final volume of $2 \mathrm{ml}$ (made up with $\mathrm{dH}_{2} \mathrm{O}$ ) using a Sequoia-Turner fluorometer (model 450; excitation $360 \mathrm{~nm}$, emission $460 \mathrm{~nm}$ ). Enzyme activity was expressed as nmol NMec released $\mathrm{min}^{-1} \mathrm{mg}^{-1} \mathrm{ESP}$, as calculated from a standard curve constructed with free NMec.

\subsection{Gelatin-substrate SDS-PAGE}

Gelatin-substrate SDS-PAGE was adapted from the method described by Heussen and Dowdle (1980). Both 3\% stacking gels and 10\% resolving gels were prepared as described (Laemmli, 1970) but with the addition of $0.1 \%$ bovine skin gelatin (Sigma) to the resolving gels. Samples incorporating $10 \mu \mathrm{l}(1.76 \mu \mathrm{g})$ ESP and $5 \mu \mathrm{l}$ sample buffer were applied to the stacking gel. Electrophoresis over $4-5 \mathrm{~h}$, at a constant current of $22 \mathrm{~mA}$, was performed at $4{ }^{\circ} \mathrm{C}$.

Following electrophoresis, gels were sliced and then washed for $90 \mathrm{~min}$ at room temperature in two changes of buffer containing $0.1 \%(\mathrm{v} / \mathrm{v})$ Triton $\mathrm{X}-100$. Gels were then incubated for $16 \mathrm{~h}$ at $37^{\circ} \mathrm{C}$ in a similar buffer, devoid of detergent; with one change after $2 \mathrm{~h}$. Buffers included $0.1 \mathrm{M}$ sodium citrate $(\mathrm{pH}=3), 0.1 \mathrm{M}$ sodium phosphate $(\mathrm{pH}=5.5)$, and $0.1 \mathrm{M}$ Tris- $\mathrm{HCl}(\mathrm{pH}=8)$. Gel slices were stained overnight in methanol: acetic acid: $\mathrm{dH}_{2} \mathrm{O}(40: 10: 50)$ containing $0.06 \%(\mathrm{w} / \mathrm{v})$ Coomassie Brilliant Blue R-250 (Sigma), and were destained for approximately $1 \mathrm{hr}$ in methanol:acetic acid: $\mathrm{dH}_{2} \mathrm{O}$ (40:10:50).

For inhibition studies, the proteinase inhibitors trans-epoxysuccinyl-L-leucylamido (4-guanidino) butane (E-64), iodoacetic acid (IA; Sigma), and ethylenediaminetetraacetic acid (EDTA) from British Drug House were employed. Prior to use, E-64 was dissolved in $10 \%(\mathrm{v} / \mathrm{v})$ dimethylsulphoxide (DMSO). Proteinase inhibitors, at a final concentration of $0.1 \mathrm{mM}$ E-64, $1 \mathrm{mM}$ IA and $10 \mathrm{mM}$ EDTA were pre-incubated with ESP for $30 \mathrm{~min}$ prior to the addition of sample buffer and were also incorporated in the washing and incubation buffers. Gelatinolytic activity was quantified using gel analysis software, GeneTools (Syngene). Molecular weight markers were as described in Section 2.

\section{Results}

\subsection{Species composition}

The species composition and relative abundance of the collected cyathostomins is represented in Table 1. 
Table 1

The relative abundance of Cyathostominea species from which ESP was collected $(n=2467)$

\begin{tabular}{lr}
\hline Species & $\%$ \\
\hline Coronocyclus coronatus & 17 \\
Coronocyclus labiatus & 1 \\
Cyathostomum catinatum & 1 \\
Cyathostomum pateratum & 9 \\
Cylicocyclus nassatus & 1 \\
Cylicocyclus leptostomum & 3 \\
Cylicocyclus insigne & 1 \\
Cylicocyclus ashworthi & 8 \\
Cylicostephanus calicatus & 6 \\
Cylicostephanus minutus & 16 \\
Cylicostephanus longibursatus & 9 \\
Cylicostephanus goldi & 1 \\
Parapoteriostomum mettami & 12 \\
Petrovinema poculatum & 1 \\
Larvae & 2 \\
Damaged/unidentifiable &
\end{tabular}

Both male and female cyathostomins are included.

\subsection{Sodium dodecyl sulphate-polyacrylamide gel electrophoresis}

Some 13 subunits were resolved between 175 and $6.5 \mathrm{kDa}$ following electrophoretic separation of $10 \mu \mathrm{l}(1.76 \mu \mathrm{g})$ ESP under non-reducing conditions. In the presence of $5 \mathrm{mM}$ DTT, some 21 subunits were resolved within the same range.

\subsection{Azocaseinolysis}

In the absence of DTT, azocaseinolysis by cyathostomin ESP was optimal at $\mathrm{pH}=4.0$ with $8.13 \mu \mathrm{g}$ azopeptides released $\mathrm{min}^{-1} \mathrm{mg}^{-1}$ protein. $47 \%$ of this activity was retained

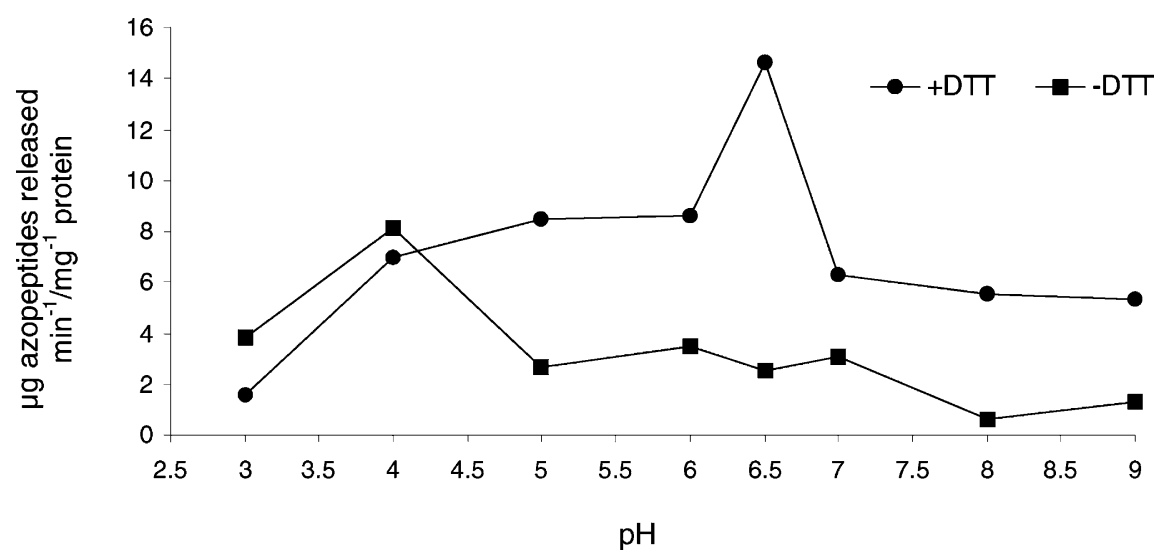

Fig. 1. pH profile of azocaseinolysis by cyathostomin ESP in the presence of $5 \mathrm{mM}$ DTT ( $)$ and in its absence (घ). 
at $\mathrm{pH}=3.0$, with $32,43,31,38,8$, and $16 \%$ persisting at $\mathrm{pH}=5.0,6.0,6.5,7.0,8.0$, and 9.0, respectively. Azocaseinolytic activity was enhanced six-fold to a maximum of $14.64 \mu \mathrm{g}$ azopeptides released $\mathrm{min}^{-1} \mathrm{mg}^{-1}$ protein in the presence of $5 \mathrm{mM}$ DTT at $\mathrm{pH}=6.5$. At $\mathrm{pH}=3.0,11 \%$ of maximal activity was retained with $47,58,59,43,38$, and $37 \%$ activity persisting at $\mathrm{pH}=4.0,5.0,6.0,7.0,8.0$, and 9.0, respectively (Fig. 1).

\subsection{Hydrolysis of synthetic substrates}

In the absence of DTT, hydrolysis of Z-Phe-Arg-NHMec by the ESP was optimal at $\mathrm{pH}=5.5$ with $2.28 \mathrm{nmol} \mathrm{NMec}$ released $\mathrm{min}^{-1} \mathrm{mg}^{-1}$ protein. $3 \%$ of this activity was retained at $\mathrm{pH}=3.0$, with $82,61,90,87,74,69$, and $97 \%$ persisting at $\mathrm{pH}=4.0,5.0,6.0$, $6.5,7.0,8.0$, and 9.0, respectively. Activity was enhanced at all $\mathrm{pH}$ values by the presence of $5 \mathrm{mM}$ DTT culminating in a six-fold increase to a maximum of $12.97 \mathrm{nmol}$ NMec released $\min ^{-1} \mathrm{mg}^{-1}$ protein at $\mathrm{pH}=5.5$. At $\mathrm{pH}=3.0,73 \%$ of activity was retained with 78,80 , $87,82,89,81$, and $62 \%$ persisting at $\mathrm{pH}=4.0,5.0,6.0,6.5,7.0,8.0$, and 9.0, respectively.

Hydrolysis of Z-Arg-Arg-NHMec was optimal at $\mathrm{pH}=4.0$ in the absence of DTT with only $1.64 \mathrm{nmol} \mathrm{NMec}$ released $\mathrm{min}^{-1} \mathrm{mg}^{-1}$ protein, which is similar to that released with Z-Phe-Arg-Arg-NHMec at the same $\mathrm{pH}$. Hydrolysis of Z-Arg-Arg-NHMec increased in the presence of $5 \mathrm{mM}$ DTT at all $\mathrm{pH}$ values except $\mathrm{pH}=4.0$, demonstrating 2-20-fold greater activity to a maximum of $4.88 \mathrm{nmol} \mathrm{NMec}$ released $\mathrm{min}^{-1} \mathrm{mg}^{-1}$ protein at $\mathrm{pH}=5.5$. This is approximately three-fold less than with Z-Phe-Arg-NHMec under the same conditions. In the presence of $5 \mathrm{mM}$ DTT, Z-Phe-Arg-NHMec was a superior substrate with a 3-30-fold higher release rate of NMec (Fig. 2). All activities were abolished by IA at a final concentration of $10 \mathrm{mM}$.

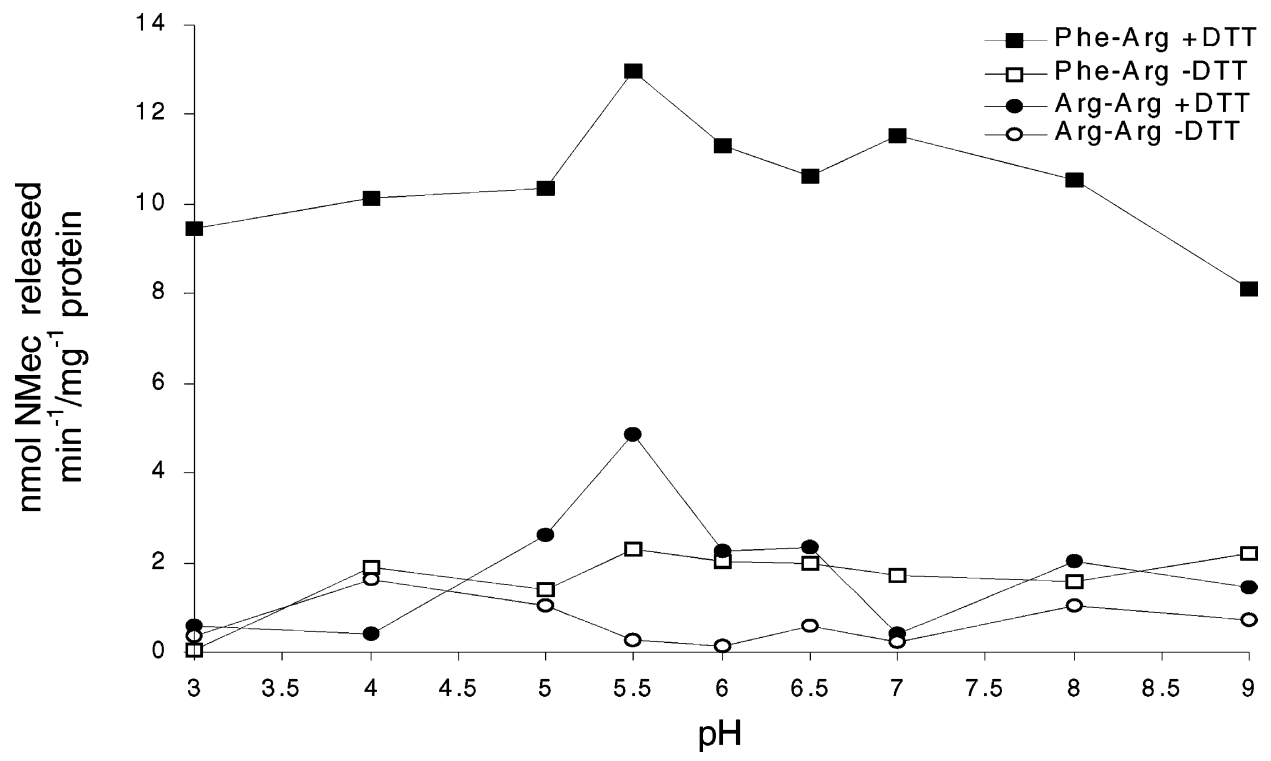

Fig. 2. pH profile of hydrolysis by ESP of the fluorogenic peptide substrates Z-Phe-Arg-NHMec ( $\square \square$ )and $\mathrm{Z}$-Arg-Arg-NHMec $(\bigcirc)$ in the presence (closed symbols) and absence of $5 \mathrm{mM}$ DTT (open symbols). 


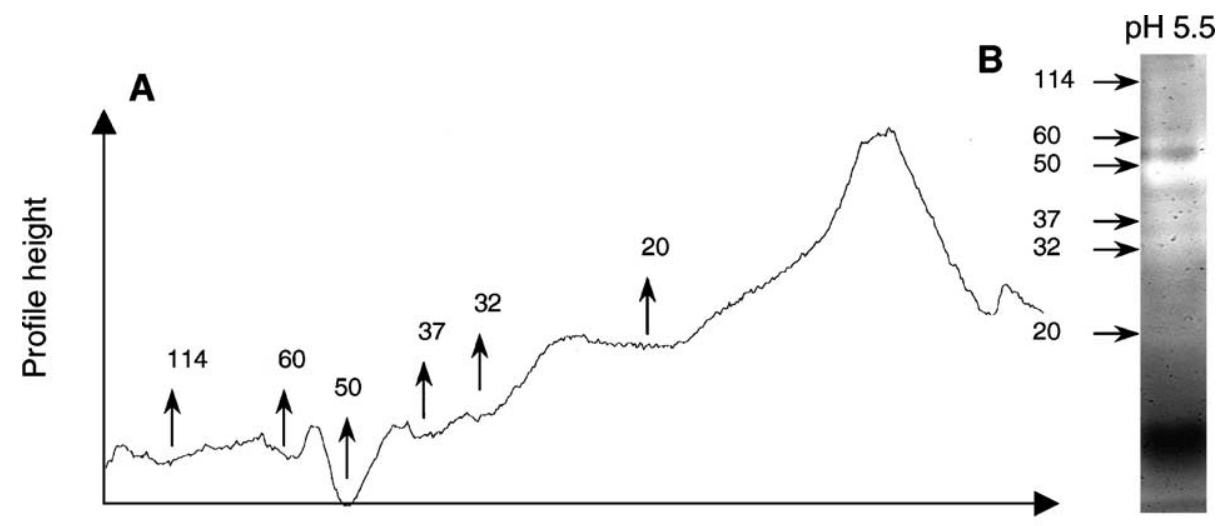

Rf Distance

Fig. 3. Gel and densitiometric scan of proteolysis by ESP in gelatin-substrate SDS-PAGE at the optimal pH of 5.5 in the presence of $5 \mathrm{mM}$ DTT. Troughs indicate gelatinolysis and profile height values represent percentage values for gelatinolysis. (A) Gelatin gel; (B) densitometric scan. Molecular weights were calculated using a molecular weight standard and GeneTools software.

\subsection{Gelatin-substrate SDS-PAGE}

In the absence of DTT, no gelatinolytic activity was detected at $\mathrm{pH}=3.0,5.5$, and 8.0. The presence of $5 \mathrm{mM}$ DTT elicited activity at both $\mathrm{pH}=5.5$ and 8.0 but not at $\mathrm{pH}=3.0$. The optimum $\mathrm{pH}$ was 5.5, resolving six bands ranging from 114 to $20 \mathrm{kDa}$; maximum activity was at $50 \mathrm{kDa}$ (Fig. 3, Table 2). At $\mathrm{pH}=8.0$ four bands were resolved, of which those at 114 and $50 \mathrm{kDa}$ demonstrated lower activity than at $\mathrm{pH}=5.5$; two additional bands were also detected at 80 and $73 \mathrm{kDa}$ (Table 2, Control).

Inhibitor studies were conducted at $\mathrm{pH}=3.0,5.5$, and 8.0 in the presence of $5 \mathrm{mM}$ DTT. EDTA enhanced activity at both $\mathrm{pH}=5.5$ and 8.0 , such that at $\mathrm{pH}=5.5$ maximum enhancement was exhibited at $32 \mathrm{kDa}$, followed by 114 and $37 \mathrm{kDa}$, but with no enhancement at 60,50 , and $20 \mathrm{kDa}$. At $\mathrm{pH}=8.0$, the EDTA was less effective in respect of these bands as none exhibited maximal activity although activities of 114 and $80 \mathrm{kDa}$ were enhanced, however, new bands were resolved at 37 and $20 \mathrm{kDa}$. The faint band detected at $50 \mathrm{kDa}$ in the absence of EDTA was not detected. EDTA had no effect at $\mathrm{pH}=3.0$. E-64 and IA abolished all activity at all $\mathrm{pH}$ values (Table 2).

\subsection{Discussion}

Cyathostomin communities comprise mixed populations and the species composition presented (Table 1) is typical of that recorded during the course of this study. Accordingly, the ESP documented is representative of a mixed cyathostomin infection. To understand the contribution of individual species, mono-specific culturing techniques will be necessary.

This study indicates the presence of cysteine-class proteinases in the ESP of Cyathostominea. Firstly, DTT $(5 \mathrm{mM})$, a cysteine proteinase activator enhanced azocaseinolysis in the $\mathrm{pH}$ range 5.0-9.0, culminating in a six-fold increase to a maximum at $\mathrm{pH}=6.5$. 
Table 2

$\mathrm{pH}$ profile of proteolytic activity by ESP as resolved by gelatin-substrate SDS-PAGE in the presence of $5 \mathrm{mM}$ DTT

\begin{tabular}{|c|c|c|c|c|c|c|c|c|c|c|c|c|}
\hline \multirow[t]{2}{*}{$M_{\mathrm{W}}(\mathrm{kDa})$} & \multicolumn{3}{|l|}{ Control } & \multicolumn{3}{|c|}{$+10 \mathrm{mM}$ EDTA } & \multicolumn{3}{|c|}{$+0.1 \mathrm{mM} \mathrm{E}-64$} & \multicolumn{3}{|c|}{$+1 \mathrm{mM}$ IA } \\
\hline & $\mathrm{pH}=3$ & $\mathrm{pH}=5.5$ & $\mathrm{pH}=8$ & $\mathrm{pH}=3$ & $\mathrm{pH}=5.5$ & $\mathrm{pH}=8$ & $\mathrm{pH}=3$ & $\mathrm{pH}=5.5$ & $\mathrm{pH}=8$ & $\mathrm{pH}=3$ & $\mathrm{pH}=5.5$ & $\mathrm{pH}=8$ \\
\hline 114 & - & ++ & + & - & +++ & ++ & - & - & - & - & - & - \\
\hline 80 & & & + & & & ++ & & & & & & \\
\hline 73 & & & + & & & + & & & & & & \\
\hline 60 & - & ++ & - & - & ++ & - & - & - & - & - & - & - \\
\hline 50 & - & +++ & + & - & +++ & - & - & - & - & - & - & - \\
\hline 37 & - & ++ & - & - & +++ & + & - & - & - & - & - & - \\
\hline 32 & - & + & - & - & +++ & - & - & - & - & - & - & - \\
\hline 20 & - & + & - & - & + & + & - & - & - & - & - & - \\
\hline
\end{tabular}

Activity scored from densitometric scans. Scores $(+++)$ 80-100\% digestion, $(++)$ 50-80\% digestion, $(+)$ 5-50\% digestion and (-) 0-5\% digestion. 
The addition of $5 \mathrm{mM}$ DTT also enhanced hydrolysis of the synthetic substrate Z-PheArg-NHMec at all $\mathrm{pH}$ values, culminating in a six-fold increase to a maximum at $\mathrm{pH}=5.5$. Hydrolysis of Z-Arg-Arg-NHMec was increased 17-fold to a maximum at $\mathrm{pH}=5.5$ in the presence of $5 \mathrm{mM}$ DTT, approximately three-fold less than with Z-Phe-Arg-NHMec under similar conditions. DTT was also required for gelatinolysis following substrate gel electrophoresis. The cysteine proteinase inhibitors E-64 $(0.1 \mathrm{mM})$ and IA $(1 \mathrm{mM})$ abolished all gelatinolytic activity in substrate gels. Furthermore, the metal chelator EDTA (10 mM), a cysteine proteinase activator, enhanced gelatinolytic activity at $\mathrm{pH}=5.5$ and 8.0.

Cysteine proteases are instrumental in various biological processes including cell death (Yuan et al., 1993), and virulence (Mottram et al., 1996). The use of the substrate Z-Phe-ArgNHMec may monitor cysteine proteinase activity as expressed by cathepsins $\mathrm{B}, \mathrm{L}$, and papain (Barrett and Kirschke, 1981; Zucker et al., 1985). The substrate Z-Arg-Arg-NHMec may be used to selectively assay for cathepsin B (Barrett and Kirschke, 1981). The present data indicate that there was proteolysis of both Z-Phe-Arg-NHMec and Z-Arg-Arg-NHMec, suggesting that this cyathostomin ESP includes cathepsin L-like, and papain- and cathepsin B-like activities. Z-Phe-Arg-NHMec was preferentially degraded over Z-Arg-Arg-NHMec and in the presence of $5 \mathrm{mM}$ DTT, at the optimum $\mathrm{pH}$ of 5.5 maximal hydrolysis of Z-Phe-Arg-NHMec was three-fold greater than that of Z-Arg-Arg-NHMec under similar conditions. This indicates that their proteolytic specificities are predominantly papain- or cathepsin L-like rather than cathepsin B-like. The high hydrolysis rate of Z-Phe-Arg-NHMec also indicates that cathepsins $\mathrm{H}, \mathrm{N}$, and $\mathrm{S}$ are not involved as cathepsin $\mathrm{H}$ does not hydrolyse this substrate, and it is a poor substrate for cathepsins N and S (Barrett and Kirschke, 1981; Maciewicz and Etherington, 1988).

Lysosomal cathepsins $\mathrm{L}$ and $\mathrm{B}$ are rapidly inactivated at $\mathrm{pH}=7.0$ and above (Kirschke and Barrett, 1987). The present data indicate that, the $\mathrm{pH}$ optimum of the ESP is 5.5-6.5. In the presence of $5 \mathrm{mM}$ DTT, activities against the substrates azocasein, Z-Phe-Arg-NHMec and Z-Arg-Arg-NHMec, were 38, 81, and 42\%, respectively of maximal at $\mathrm{pH}=8.0$, and 37,62 , and $30 \%$, respectively at $\mathrm{pH}=9.0$. Furthermore, at $\mathrm{pH}=8.0$ considerable gelatinolytic activity was detected in substrate gels both in the presence and absence of EDTA. As such, it seems that the proteolytic activity of the ESP is more like that of papain which displays activity well into the alkaline $\mathrm{pH}$ range (Zucker et al., 1985), and has a pH optimum of 5.0-7.0 (Boller, 1986). Such proteolytic activity by the ESP seems appropriate as the $\mathrm{pH}$ of equine caecal contents may vary between $\mathrm{pH}=5.9$ and 7.8 , depending on both diet and time after feeding (Goodson et al., 1985).

Cysteine-class proteinases have been documented for many other parasitic helminths including Strongylus vulgaris, Nippostrongylus brasiliensis, and Strongyloides ratti (Caffrey and Ryan, 1994; Kamata et al., 1995; Harrop et al., 1995, respectively). In H. contortus cysteine proteinases degrade the matrix of host connective tissue (Rhoads and Fetterer, 1996), inhibit the clotting of sheep blood, and hydrolyse haemoglobin; their activity was characterised as cathepsin L-like (Rhoads and Fetterer, 1995). The dominant intestinal transcripts were represented by cathepsin B-like cysteine proteinase genes (cbls) (Jasmer et al., 2001) and substrate based histological analysis located their products in the intestinal microvilli (Shompole and Jasmer, 2001). Cysteine proteinases are proven vaccine immunogens in helminthiases, as immunization with cathepsin L-like proteinases of $F$. hepatica elicited more than $50 \%$ protective immunity in cattle (Dalton et al., 1996). Furthermore, the 
potential of cysteine protease inhibitors in the therapeutic control of parasites has elicited much interest. Peptidyl fluoromethyl ketones and peptidyl methyl ketones effectively inhibit haemoglobin degradation, which results in the death of schistosomules both in vitro and in vivo (Wasilewski et al., 1996). The present data are derived from assemblages of Cyathostominea and thus represent a first approximation. The use of ESP constituents as leads in immunological or chemical control of these parasites will require characterization of ESP from at least the principal individual species.

\section{Acknowledgements}

We thank Dr. Wen-Yuan Chung for technical assistance and Mr. Ray Magee of the Irish Horse Abattoir Trading Co. Ltd.

\section{References}

Abbott, E.M., 1998. Larval cyathostomosis. Part 1. The disease, its diagnosis and treatment. Equine Pract. 20, $6-7$.

Barrett, A.J., Kirschke, H., 1981. Cathepsin B, H, and L. Methods Enzymol. 80, 535-561.

Boller, T., 1986. Roles of proteolytic enzymes in interactions of plants with other organisms. In: M.J. Dalling (Ed.), Plant Proteolytic Enzymes. CRC Press, Boca Raton, FL, pp. 68-96.

Bradford, M.M., 1976. A rapid and sensitive method for the quantitation of microgram quantities of protein utilizing the principle of protein-dye binding. Anal. Biochem. 72, 248-254.

Caffrey, C.R., Ryan, M.F., 1994. Characterization of proteolytic activity of excretory-secretory products from adult Strongylus vulgaris. Vet. Parasitol. 52, 285-296.

Cornelissen, J.B.W.J., Gaasenbeek, C.P.H., Borgsteede, F.H.M., Holland, W.G., Harmsen, M.M., Boersma, W.J.A., 2001. Early immunodiagnosis of fasciolosis in ruminants using recombinant Fasciola hepatica cathepsin L-like protease. Int. J. Parasitol. 31, 728-737.

Dalton, J.P., McGonigle, S., Rolph, T.P., Andrews, S.J., 1996. Induction of protective immunity in cattle against infection with Fasciola hepatica by vaccination with cathepsin L proteinases and with hemoglobin. Infect. Immun. 64, 5066-5074.

Gawor, J.J., 1995. The prevalence and abundance of internal parasites in working horses autopsied in Poland. Vet. Parasitol. 58, 99-108.

Goodson, J., Tyznik, W.J., Dehority, B.A., Cline, J.H., 1985. Effects of an abrupt change from all hay to all concentrate on anaerobic bacterial numbers (grown on selective media), protozoal numbers and $\mathrm{pH}$ of the caecum. In: Proceedings of the 9th Equine Nutrition and Physiology Symposium, 23-25 May 1985, Equine Nutrition and Physiology Society at Michigan State University, East Lansing, MI, pp. 52-63.

Gotz, B., Klinkert, M.Q., 1993. Expression and partial characterization of a cathepsin B-like enzyme (Sm31) and a proposed haemoglobinase (Sm32) from Schistosoma mansoni. Biochem. J. 290, 801-806.

Grogan, J., Rotmans, P., Ghoneim, H., Deelder, A., Yazdanbakhsh, M., Klinkert, M.Q., 1997. Recognition of Schistosoma mansoni cathepsins B and L by human IgG1 and IgG4 antibodies. Parasite Immunol. 19, 215-220.

Halton, D.W., 1997. Nutritional adaptations to parasitism within the platyhelminthes. Int J. Parasitol. 27, 693-704.

Harrop, S.A., Prociv, P., Brindley, P.J., 1995. Amplification and characterization of cysteine proteinase genes from nematodes. Trop. Med. Parasitol. 46, 119-122.

Heussen, C., Dowdle, E.B., 1980. Electrophoretic analysis of plasminogen activators in polyacrylamide gels containing sodium dodecyl sulfate and copolymerized substrates. Anal. Biochem. 102, 196-202.

Ikeda, T., Oikawa, Y., Nishiyama, T., 1996. Enzyme-linked immunosorbent assay using cysteine proteinase antigens for immunodiagnosis of human paragonimiasis. Am. J. Trop. Med. Hyg. 55, 434-437.

Jasmer, D.P., Roth, J., Myler, P.J., 2001. Cathepsin B-like proteases and Caenorhabditis elegans homologues dominate gene products expressed in adult Haemonchus contortus intestine. Mol. Biochem. Parasitol. 116 (2), 159-169. 
Kamata, I., Yamada, M., Uchikawa, R., Matsuda, S., Arizono, N., 1995. Cysteine protease of the nematode Nippostrongylus brasiliensis preferentially evokes an IgE/IgG1 antibody response in rats. Clin. Exp. Immunol. 102, 71-77.

Kirschke, H., Barrett, A.J., 1987. Chemistry of lysosomal proteases. In: Glaumann, H., Ballard, F.J. (Eds), Lysosomes: Their Role in Protein Breakdown. Academic Press, London, pp. 193-238.

Laemmli, U.K., 1970. Cleavage of structural proteins during the assembly of the head of bacteriophage T4. Nature $227,680-685$.

Langrova, I., 1998. Seasonal prevalence and intensity of faecal helminth egg (larval) output in various categories of herds of horses during two grazing seasons. Helminthologia-Bratislava 35, 43-50.

Lichtenfels, J.R. 1975. Helminths of domestic equids. Illustrated keys to genera and species with emphasis on North American forms. In: Proceedings of the Helminthological Society of Washington, Vol. 42. pp. 1-92 (special issue).

Lichtenfels, J.R., Kharchenko, V.A., Sommer, C., Ito, M., 1997. Key characters for the microscopical identification of Cylicocyclus nassatus and Cylicocyclus ashworthi (nematoda: Cyathostominae) of the horse, Equus caballus. J. Helminthol. Soc. Wash. 64, 120-127.

Lichtenfels, J.R., Kharchenko, V.A., Krecek, R.C., Gibbons, L.M., 1998. An annotated checklist by genus and species of 93 species level names for 51 recognized species of small strongyles (nematoda: Strongyloidea: Cyathostominea) of horses, asses and zebras of the world. Vet. Parasitol. 79, 65-79.

Love, S., McKeand, J.B., 1997. Cyathostomosis: practical issues of treatment and control. Equine Vet. Edu. 9 , 253-256.

Maciewicz, R.A., Etherington, D.J., 1988. A comparison of four cathepsins (B, L, N and S) with collagenolytic activity from rabbit spleen. Biochem. J. 256, 433-440.

Mair, T.S., Pearson, G.R., 1995. Multifocal non-strangulating intestinal infarction associated with larval cyathostomiasis in a pony. Equine Vet. J. 27, 154-155.

Mair, T.S., Sutton, D.G., Love, S., 2000. Caecocaecal and caecocolic intussusception associated with larval cyathostomosis in four young horses. Equine Vet. J. 32 (Suppl.), 77-80.

Matthews, A.G., Morris, J.R., 1995. Cyathostomiasis in horses. Vet. Rec. 136, 52.

Morris, S.R., Sakanari, J.A., 1994. Characterization of the serine protease and serine protease inhibitor from the tissue-penetrating nematode Anisakis simplex. J. Biol. Chem. 269, 27650-27656.

Mottram, J.C., Souza, A.E., Hutchison, J.E., Carter, R., Frame, M.J., Coombs, G.H., 1996. Evidence from disruption of the lmcpb gene array of Leishmania mexicana that cysteine proteinases are virulence factors. Proc. Nat. Acad. Sci. 93, 6008-6013.

Murphy, D., Keane, M.P., Chandler, K.J., Goulding, R., 1997. Cyathostome-associated disease in the horse: investigation and management of four cases. Equine Vet. Edu. 9, 247-252.

Rhoads, M.L., Fetterer, R.H., 1995. Developmentally regulated secretion of cathepsin L-like cysteine proteases by Haemonchus contortus. J. Parasitol. 81 (4), 505-512.

Rhoads, M.L., Fetterer, R.H., 1996. Extracellular matrix degradation by Haemonchus contortus. J. Parasitol. 82 (3), 379-383.

Shompole, S., Jasmer, D.P., 2001. Cathepsin B-like cysteine proteases confer intestinal cysteine protease activity in Haemonchus contortus. J. Biol. Chem. 276 (4), 2928-2934.

Smith, A.M., Dowd, A.J., Heffernan, M., Robertson, C.D., Dalton, J.P., 1993. Fasciola hepatica: a secreted cathepsin L-like proteinase cleaves host immunoglobulin. Int. J. Parasitol. 23, 977-983.

Smith, A.M., Dalton, J.P., Clough, K.A., Kilbane, C.L., Harrop, S.A., Hole, N., Brindley, P.J., 1994. Adult Schistosoma mansoni express cathepsin L proteinase activity. Mol. Biochem. Parasitol. 67, 11-19.

Song, C.Y., Kim, T.S., 1994. Characterization of a cysteine proteinase from adult worms of Paragonimus westermani. Korean J. Parasitol. 32, 231-241.

Uhlinger, C., 1990. Effects of three anthelmintic schedules on the incidence of colic in horses. Equine Vet. J. 22, 251-254.

Wasilewski, M.M., Lim, K.C., Phillips, J., McKerrow, J.H., 1996. Cysteine protease inhibitors block schistosome hemoglobin degradation in vitro and decrease worm burden and egg production in vivo. Mol. Biochem. Parasitol. 81, 179-189.

Yuan, J., Shaham, S., Ledoux, S., Ellis, H.M., Horvitz, H.R., 1993. The Caenorhabditis elegans cell death gene ced-3 encodes a protein similar to mammalian interleukin-1-beta-converting enzyme. Cell 75, 641-652.

Zucker, S., Buttle, D.J., Nicklin, M.J.H., Barrett, A.J., 1985. The proteolytic activities of chymo-papain, papain and papaya proteinase. Part III. Biochim. Biophys. Acta. 828, 196-204. 